\title{
18. Rethinking urbanisation, development, and collective action in Indonesia
}

Rita Padawangi

The term 'development' on its own indicates progress towards becoming more advanced. In most of today's urbanisation, however, the term 'urban development' has implied a capitalist mode of production in which planners consider capitalism the most rational way of managing and distributing space in everyone's best interests (Stein 2019). As a result, many urban developments around the world have normalised social inequalities for the sake of economic efficiency in the profit-making scheme of spatial distribution. The COVID-I9 pandemic, however, exposed social inequalities that had been 'normalised' in 'normal' times. For example, Singapore won worldwide praise for curbing infection levels in the first month of the pandemic, only to see it spike tremendously by the end of March 2020 (Kurohi 2020; Ng 2020). The initial measures missed migrant workers in dormitories; many were construction workers in Singapore, but their living quarters were segregated from most of the population. Once the virus reached the dormitories, dense living conditions made physical distancing difficult, and towards the end of June 2020 there were more than 40,000 COVID-I9 cases among migrant workers in dormitories. There was also panic buying across supermarkets in the early days of the virus's spread in Singapore (Chang 2020), an indication of perceived insecurity in a crisis.

Normalcy implies the status quo, which might include the social inequalities, discrimination, and even oppression that were taken for granted in everyday situations. In the context of capitalist urban development, the constant presumption of economic growth as the main indicator of development has normalised the relegation of other aspects of societal progress to lesser importance (Friedmann I992). The ready association of gross national product (GNP) per capita with livelihood

How to cite this book chapter:

Padawangi, Rita. 2022. 'Rethinking urbanisation, development, and collective action in Indonesia'. In: Shin, Hyun Bang; Mckenzie, Murray; and Oh, Do Young (eds) COVID-I 9 in Southeast Asia: Insights for a post-pandemic world. London: LSE Press, pp. 205-2I7. DOI: https://doi.org/IO.3I389/lsepress.cov.r License: CC BY 4.०. 
improvements has been applied almost universally throughout world economies despite the known shortcomings of using income as a measure of progress, as it neglects the human scale and social-environmental interconnectedness across borders. As a result, urbanisation around the world has continued to decrease space for various communities who become collateral to development, such as farmers, fisherfolk, and adat (traditional) societies. They are underappreciated when unquantifiable aspects of social-cultural life are converted into quantified economic valuation. Those who are collateral to development comprise everyone on the margins, including the urban poor, who have often been targets of forced evictions (Padawangi 20I9a).

The domination of the capitalist urban development paradigm has had both ideological and pragmatic impacts. On the pragmatic side, development strategies have been in favour of the drive to urbanise. Singapore, for example, has achieved accelerated development since the I960s through an economic restructuring that transformed an agricultural society into an industrial one. Agriculture was significantly reduced, as it contradicted the city-state's land-scarce development strategy. Singapore's position as the wealthiest city-state in Southeast Asia subsequently became a development model for the entire world. The desirability of this development model was further cemented by the global city's image as a cultural hub, formed through the construction of large-scale facilities for arts and culture, in connection with the city's function as an economic hub (Kong 20I0; Yeoh 2005).

Yet, cities' economic superiority has relied on footprints beyond their territories, as cities have been dependent on the countryside for resources. Urbanisation has taken up fertile land, rice fields, and forests to extract natural resources through mining as well as building roads, airports, houses, condominiums, and new towns (Spinney 2020). Simultaneously, spaces in the city that attract more investment have often relied on crowding people in high density to maximise profit (Luscombe 2020). In the process, these developments have increased the likelihood of zoonosis and other infectious diseases and have also made urban spaces products to be traded in the market economy (Spinney 2020). Consequently, social inequalities have been apparent in spatial inequalities that limit livelihood improvement opportunities for marginalised groups and affect access to health services and environmental quality.

Activists and scholars have questioned 'normalcy' through the critical rethinking of urbanisation and have thus called for alternative 
visions of it (Brenner, Marcuse and Mayer 20I2; Cabannes, Douglass, and Padawangi 2019; Lefebvre 2003). They have called for increased attention to people's actions to change the city in order to change society (Castells I983), to 'rethink the economy' by carefully analysing social relations rather than income per se (Friedmann I992, p.44), and to look at the smallest units of society as social, political, and economic agents (Cabannes, Douglass, and Padawangi 2019). Looking beyond state interventions has been important to examine possible alternatives. In Southeast Asia, excluding Singapore, the state's limitations have been obvious in the mismatch between master plans and everyday realities. With these limits on state capacity, collective actions in civil society have yielded important social dynamics in Southeast Asia. After recent natural disasters, such as typhoons in the Philippines and earthquakes in Indonesia, local and transborder collective actions like aid deliveries and empowerment programmes have been particularly important.

How have collective actions from civil society members and groups responded to the pandemic? What have been their limitations? What could we learn from the dynamics of Southeast Asia's collective action in questioning normalcy in today's urban development? Collective action comprises 'purposive, meaningful, and potentially creative' ways to challenge political establishments (Chesters and Welsh 20II, p.5). Examinations into local efforts to 'counter the alienating forces of capitalist urban growth' (Cabannes, Douglass, and Padawangi 20I9, p.I6) have been of central importance in understanding how, why, and how far collective action could challenge presupposed notions of 'normal' urban development (Harvey 2020). In Southeast Asia, these collective responses have emerged through existing networks of civil society groups and citizens. From self-imposed area quarantines to food-sharing, crowdfunding, and collective farming, crisis-activated actions have effectively countered the market-driven production of urban space. In addressing the questions on the process of collective action responses, limitations, and connecting collective action with today's urban development, there are two important considerations: first, the perspective of the actors on the ground in social mobilisation during a crisis has been key to understanding the processes behind these responses, and, second, actions that aim to question normalcy and create lasting change require sustainability. These two considerations are elaborated below.

First, since actions on the ground have been of key importance, we need to look at neighbourhoods as a group of households that can make collective decisions on local spatial governance (Beard and 


\section{Figure 18.1. Gatekeepers at Kampung Akuarium, Jakarta}

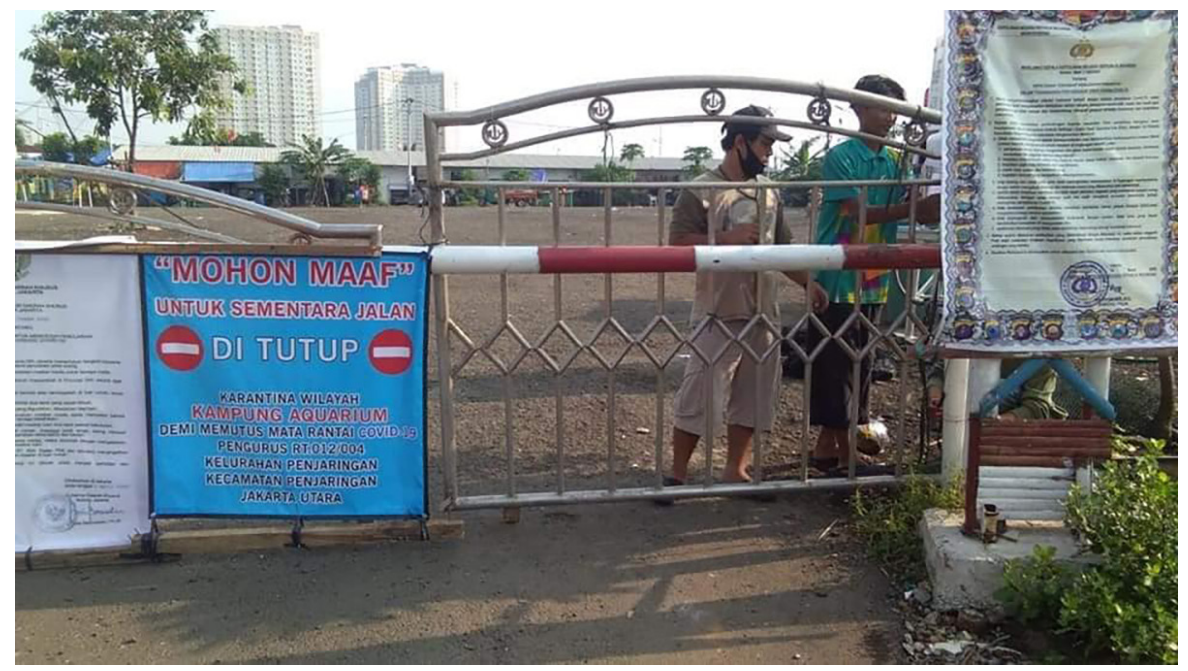

Source: Dharma Diani (2020).

Dasgupta 2006). The COVID-I9 pandemic provided a window onto the collective abilities of neighbourhoods in making purposive decisions for the public good in the absence of authoritative government responses to protect public health. A case in point is Jakarta, where the pandemic's early months became a stage for political competition: national elites opposed measures by the local governor-cum-political rival at the expense of public health (Jaffrey 2020). Amid this situation, various neighbourhoods took action, from restricting movements through collective guarding to disinfecting public spaces. For example, a poor urban neighbourhood in north Jakarta, Kampung Akuarium, imposed movement restrictions as early as 9 March 2020, before the city implemented official restrictions. Subsequently, residents built a gate and assigned shifts to guard the checkpoint (Figure I8.I). Local initiatives to curb large gatherings and encourage public health measures like mask-wearing occurred in various neighbourhoods across Indonesia (Figure I 8.2), showing how collective actions were geared towards protecting shared spaces.

Amid the popularity of the 'cities as engines of economic growth' paradigm (Colenbrander 20I6), the pandemic was also a reminder of the importance of food security. In Indonesia, food production has very much been a part of many societies' traditional cultural practices, but capitalist urban development has reduced the space to do so. Traditional fisherfolk in Jakarta Bay, for instance, have been sidelined for real estate-driven reclamation projects (Padawangi 20I9b). The fertile island of Java is 


\section{Figure 18.2. Mask mandate banner in Kampung Peneleh, Surabaya}

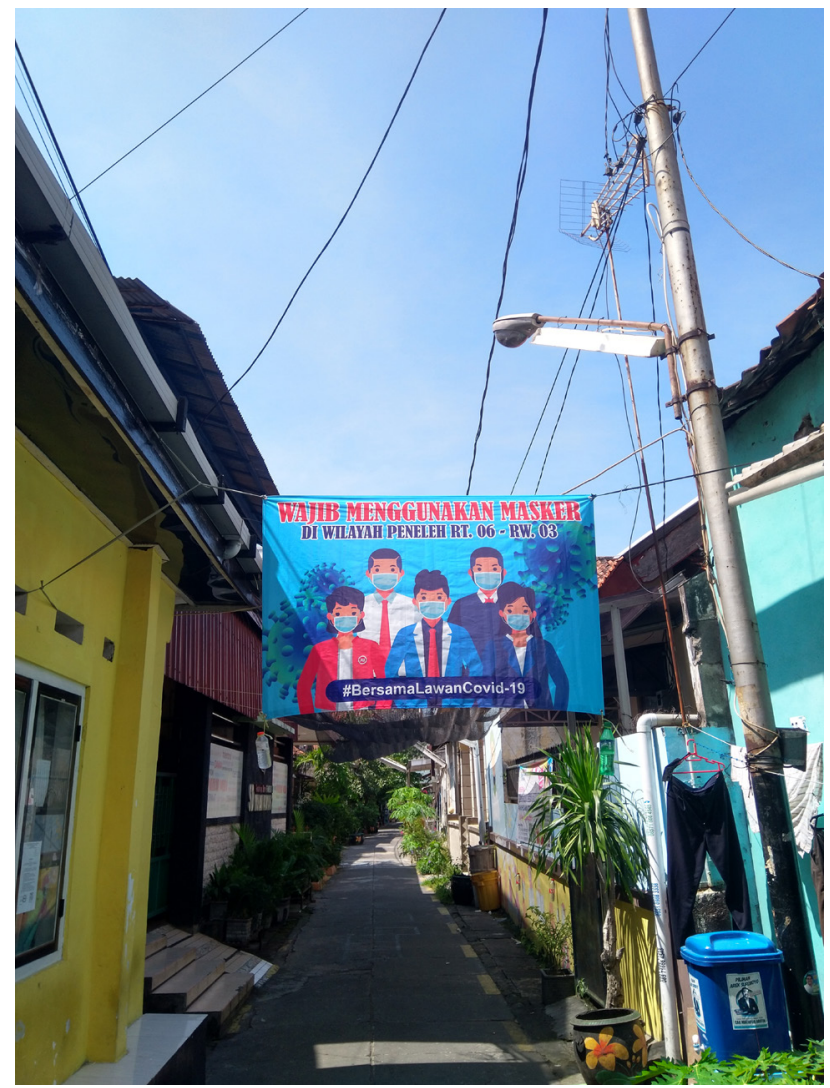

Source: Muhamad Rohman Obet (2020).

also the most populated and most industrialised. Even in a place like Bali, where agriculture is still tied to everyday life, the share of agriculture in the province's economy has continued to decline, in contrast with the growing share of tourism-related trade and services (Figure I8.3). Global tourism that is 'good' for the economy has threatened the sustainability of subak - the thousand-year-old traditional water management system for irrigation - as agricultural land use has competed with tourism (Salamanca et al. 2015). Such dependency on global tourism became the economy's Achilles' heel during the pandemic.

Therefore, it is unsurprising that a popular collective action during the pandemic was the return to farming. A group of youths called Serikat Tani Kota Semarang (STKS), for example, started cultivating unused land on the fringes of the city during the pandemic. There were also groups of youths in Bali who went back to farming as the urbanised, touristified economy ground to a halt (Firdaus 2020; Muhajir and 


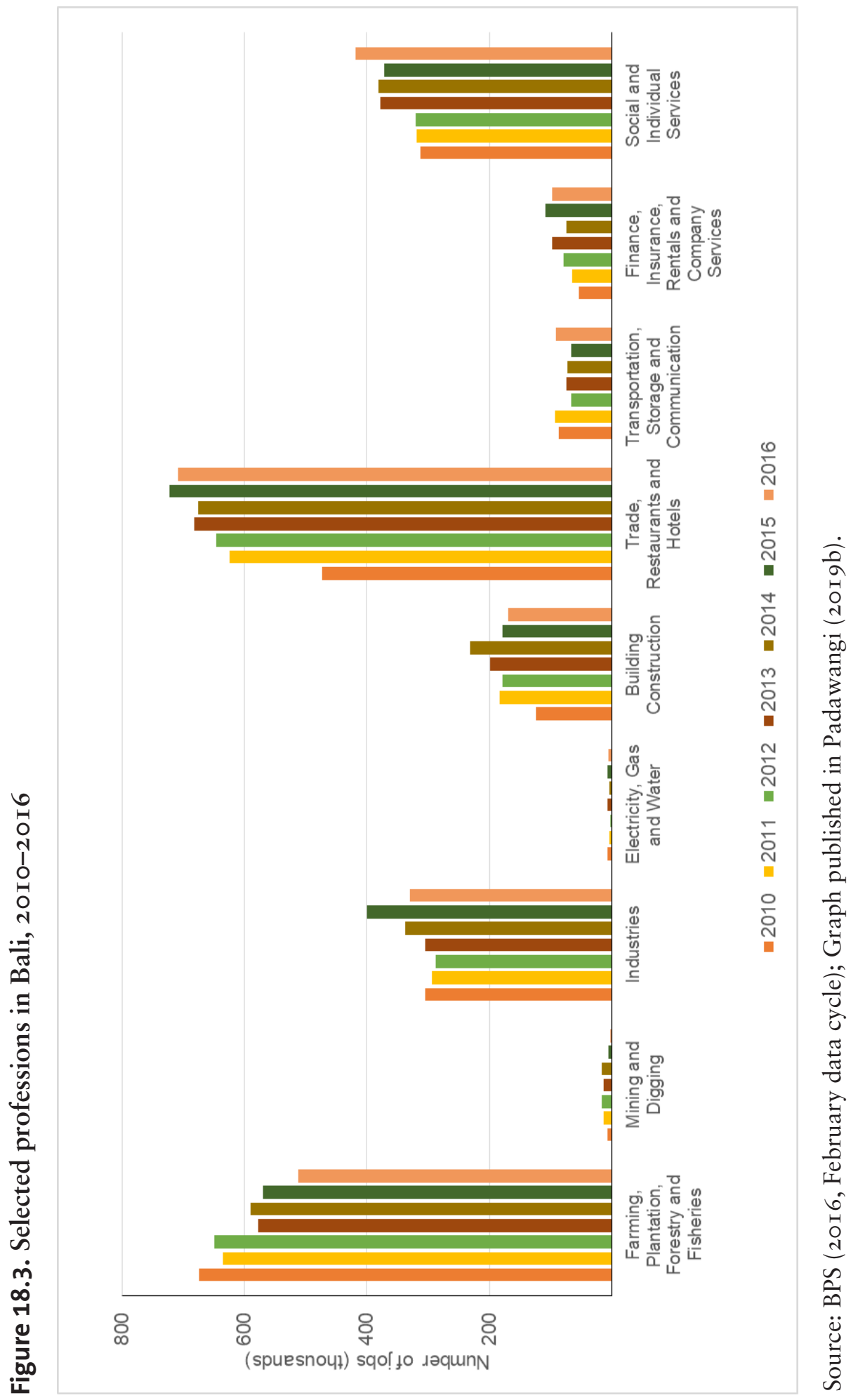


Figure 18.4. 'Punk-Pangan' - free vegetable distribution at WALHI, Denpasar

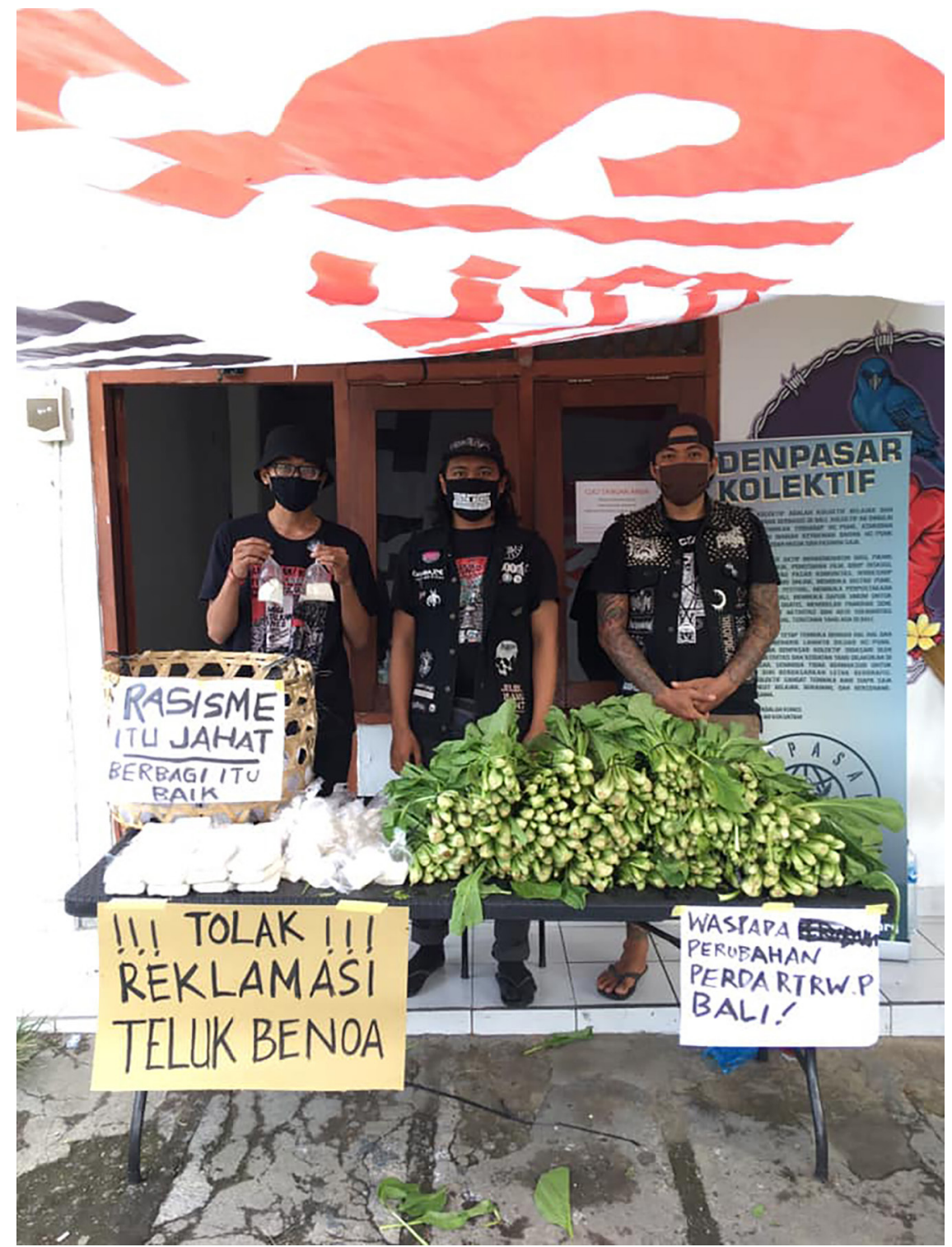

Source: Gilang Pratama (2020).

Suriyani 2020). The return to farming (and fishing) also corresponded with food-sharing initiatives; for example, Denpasar Kolektif (Denpasar Collective), a hardcore punk community, initiated 'Punk-Pangan' (Punks for Food) to regularly distribute free vegetables at the offices of Wahana Lingkungan Hidup (WALHI) (Figure I 8.4). The distribution 
of free vegetables also created space for greater advocacy against laws, projects, and practices considered harmful to the environment, such as the Benoa Bay reclamation and changes to the spatial planning, mining, and 2020 national omnibus 'job creation' laws. WALHI itself is an environmental NGO known for its advocacy activities for environmental issues in Indonesia; hence, the distribution of free vegetables at their offices, interspersed with handwritten advocacy posters on the table where they placed the vegetables, made the pandemic moment into a call for collective action to address wider environmental issues. In the case of STKS, the youths also developed training on the basic techniques of farming and food processing alongside classes on philosophical and sociological concepts that questioned capitalist development, including critical topics such as agrarian social movements, feminism, and ecology (STKS 2020).

These farming movements are examples of collective actions that were both pragmatic and political. By demonstrating society's ability to continue functioning socially, economically, and culturally, they promoted a message of resilience. Compared to the panic buying of basic supplies in cities like Hong Kong, Singapore, and Jakarta at the start of the pandemic, this association between farming and resilience was situated in the pandemic as a critique of 'cities as engines of economic growth' as an unsustainable paradigm that exploits the countryside for resources (Tacoli 1998). In practice, these farmers' collectives ranged from very pragmatic ones - choosing farming after being laid off from service jobs, for example - to ideologically purposive ones - challenging urban development trajectories and promoting ecological-environmental sustainability. Nevertheless, the promotion of resilience in farming as a form of collective action makes farming a 'purposive, meaningful, and potentially creative' way to challenge political establishments (Chesters and Welsh 20II, p.5), especially when they had regularly evicted farmers to develop infrastructure for urban economies.

Second, collective actions transcended beyond local neighbourhoods through peer-to-peer citizens' networks. Where government interventions were lacking and corporations' activities were slowed down, existing networks marshalled food resources from the countryside. Bursts of crowdfunding initiatives in the Philippines, Indonesia, and Singapore during the pandemic constituted collective actions beyond their immediate spatial territories. It is, however, fair to question the sustainability of these initiatives. Nathalie Dagmang (2020), an activist in Manila, said: 
It feels frustrating knowing that what we were doing was still inefficient and unsustainable. The government has all the resources, communication channels, control over transportation, and the personnel for checkpoints and local units. They are the ones mandated, by virtue of our votes and taxes, to provide for our needs during calamities such as this. But where are they now?

These initiatives highlighted the lack of state capacity in these countries, and the sustainability of citizens' collective actions depended on their ability to evolve into a structured societal alternative.

On the one hand, the pandemic provided a political opportunity for collective actions that advocated for societal change. Restrictions on physical spaces for gatherings intensified the use of technology as a public sphere. For instance, Kampung Akuarium in Jakarta continued their ongoing land reform process through online meetings with government officials. Protests and discussions occurred online, covering issues such as environmental sustainability, critical thoughts on urbanisation-as-usual, and the distribution of land and agrarian reform. Examples of these online actions included the 'People's Court' (Sidang Rakyat) on I June 2020, which was facilitated by the Indonesia Legal Aid Foundation to gather testimonies of witnesses from many parts of Indonesia to demand revocation of the new mining law. Online-offline alliances also opened up possibilities to connect distant geographies to build solidarity, such as the crowdfunding initiative to buy rice from cement factory-threatened farmers in Central Java for the urban poor in Jakarta.

On the other hand, overreliance on the online sphere might perpetuate larger social inequalities in access to technology. Furthermore, there were signs of pandemic-induced shrinkage of civic spaces following restrictions on public gatherings, cuts in funding for democracy and human rights advocacy, movement restrictions, and further limitations on freedom of speech (Gomez and Ramcharan 2020). Restrictions in the name of preventing the virus's spread might have also functioned as tools of repression. As the pandemic lingered, citizens' attitudes shouldered the blame. The 'new normal' emerged as a popular term to represent living with the virus as a given reality while minimising its spread. However, the term carries urban-biased assumptions. The eagerness to practise the 'new normal', largely defined by hygiene practices and regulations on social distancing, reduced the role of citizens in pandemic alleviation to merely abiding by the rules. Such a 'new normal', while logically correlated to curbing the spread of the virus, reduced the 
problem to citizens' attitudes rather than questioning the larger problem of inequality in 'normal' urban development trajectories. While there have been legitimate questions on how citizens' lack of discipline worsened the pandemic, seeing the persistence of the pandemic solely as a problem of discipline increases the appeal of authoritarianism. Celebrating the achievements of countries that took more authoritarian approaches to containing the pandemic weakened the political opportunity to advocate for alternative societal structures and urban development paradigms. COVID-I9 thus called into question 'the ability of the democratic model to cope with devastating events' (Belin and De Maio 2020, p.I).

The COVID-I9 pandemic demonstrated how collective action could provide alternatives to 'normal' urbanisation through action on the ground, activating networks, and intensifying the use of an online public sphere. These collective actions highlighted alternatives to the 'normal' supply chain, the 'normal' competitive economy, and the 'normal' obsession with skyscrapers and buildings. The ability to collectively act and function autonomously in the local context - socially, economically, and culturally - allowed citizens to continue thriving during a crisis. These actions largely consisted of simple gestures in social relationships, care for the environment, and making economies relevant to the everyday life of the land. The sustainability of these alternatives, however, was also affected by the availability of space, resources, and time. With governments and economic powers actively promoting 'new normal' narratives, existing social inequalities and environmental issues could remain unresolved, potentially affecting spaces for collective actions that need to continue evolving to sustain their momentum.

\section{Acknowledgements}

I am grateful to Muhamad Rohman Obet and Nathalie Dagmang, and to the Southeast Asia Neighborhoods Network (SEANNET) in general, for the discussions, sharing of experiences, and solidarity that makes this chapter possible. I thank the Henry Luce Foundation for its funding support for SEANNET. I would also like to thank Ibu Dharma Diani (Kampung Akuarium), Gilang Pratama (Denpasar Kolektif, ForBALI, WALHI Bali), Asfinawati (Yayasan Lembaga Bantuan Hukum Indonesia/YLBHI), and Bosman Batubara (Serikat Tani Kota Semarang/STKS) for the sharing of ideas and their support, as well as for their consistency and resilience. Last but not least, I thank the editors for their feedback and for making this publication possible. 


\section{References}

Beard, Victoria A.; and Dasgupta, Aniruddha. (2006). 'Collective action and community-driven development in rural and urban Indonesia'. Urban Studies, vol.43, no.9, pp. I45 I-I 468. https://doi.org/Io.Io80/00420980600749944

Belin, Célia; and De Maio, Giovanna. (2020). Democracy after Coronavirus: Five Challenges for the 2020s. USA: Brookings Institution. https://perma.cc $/ \mathrm{SYJ}_{7}-\mathrm{S}_{7} \mathrm{SZ}$ [Last accessed I May 2021].

Brenner, Neil; Marcuse, Peter; and Mayer, Margit. (eds) (2012). Cities for People, Not for Profit: Critical Urban Theory and the Right to the City. UK: Routledge.

Cabannes, Yves; Douglass, Mike; and Padawangi, Rita. (eds) (2019). Cities in Asia by and for the People. Netherlands: Amsterdam University Press.

Castells, Manuel. (1983). The City and the Grassroots: A Cross-Cultural Theory of Urban Social Movements. USA: University of California Press.

Chang, Nicole. (2020). 'COVID-I9: Supply chain remains robust, "panic buying” situation has stabilised, says Lawrence Wong'. CNA, I2 February. https://perma.cc/7YY9-SK6G [Last accessed I May 202I].

Chesters, Graeme; and Welsh, Ian. (20II). Social Movements: The Key Concepts. UK: Routledge.

Colenbrander, Sarah. (2016). Cities as Engines of Economic Growth: The Case for Providing Basic Infrastructure and Services in Urban Areas. UK: International Institute for Environment and Development Working Paper. https://perma.cc/G3 CE-2SM7 [Last accessed I May 202I].

Dagmang, Nathalie D. (2020). 'Responding to Escolta's street vendors: How do we provide relief and security to the economically vulnerable?' Bulatlat, 2 May. https://perma.cc/NUH3-RDM6 [Last accessed I May 202I]

Firdaus, Febriana. (2020). “Bali is not only about tourism”: Covid-I9 prompts rethink for island's residents'. The Guardian, I August. https://perma.cc $1523 \mathrm{Z}-\mathrm{CHJ} 7$ [Last accessed I May 202 I].

Friedmann, John. (I992). Empowerment: The Politics of Alternative Development. UK: Blackwell.

Gomez, James; and Ramcharan, Robin. (2020). 'COVID-I9 shrinks civil space in Southeast Asia'. Jakarta Post, 25 April. https://perma.cc/C6RN-YNVN [Last accessed I May 202I].

Harvey, David. (2020). 'We need a collective response to the collective dilemma of coronavirus'. Jacobin, ${ }_{4}$ April. https://perma.cc/Y9QK-A3 $\mathrm{A}_{7}$ [Last accessed I May 202I]. 
Jaffrey, Sana. (2020). 'Coronavirus blunders in Indonesia turn crisis into catastrophe'. Carnegie Endowment for International Peace, 29 April. https:// perma.cc/YK3 $\mathrm{T}$-VQFX [Last accessed 22 January 202I].

Kong, Lily. (2007). 'Cultural icons and urban development in Asia: Economic imperative, national identity, and global city status'. Political Geography, vol. 26, no. 4, pp. 383-404. https://doi.org/IO.IOI6/j.polgeo.2006.I I.007

Kurohi, Rei. (2020). 'S'pore is gold standard for case detection: Harvard study'. Straits Times, I 8 February. https://perma.cc/M6WU-R933 [Last accessed io July 2020].

Lefebvre, Henri. (2003). The Urban Revolution. USA: University of Minnesota Press.

Luscombe, Belinda. (2020). 'Architect Rem Koolhaas says redesigning public spaces was necessary before the pandemic'. Time, I4 May. https://perma.cc 19TJR-Z9C8 [Last accessed I May 202I].

Muhajir, Anton; and Suriyani, Luh De. (2020). 'Geliat petani muda Bali di tengah pandemic Covid-ı9'. Mongabay, I2 May. https://perma.cc/2 $\mathrm{G}_{4} \mathrm{C}$ -BX6T [Last accessed I May 202I].

Ng, Eileen. (2020). 'Singapore battles virus hotspots in migrant workers' dorms'. Associated Press, Io April. https://perma.cc/EA9S-BX2Z [Last ac cessed I May 202I].

Padawangi, Rita. (2019a). 'Forced evictions, spatial (un)certainties and the making of exemplary centres in Indonesia'. Asia-Pacific Viewpoint, vol. 6o, no. I, pp. 65-79. https://doi.org/IO.I I I I/apv.I22I3

Padawangi, Rita. (2019b). 'Urban development, vulnerabilities, and disasters in Indonesia's coastal land reclamations: Does social justice matter?' in Lisa Reyes Mason and Jonathan Rigg (eds) People and Climate Change: Vulnerability, Adaptation, and Social Justice. UK: Oxford University Press, pp. I22-I46. https://doi.org/IO.I093/oso/9780I90886455.003.0007

Salamanca, Albert M.; Nugroho, Agus; Osbeck, Maria; Bharwani, Sukaina; and Dwisasanti, Nina. (2015). Managing a Living Cultural Landscape: Bali's Subaks and the UNESCO World Heritage Site. Thailand: Stockholm Environment Institute Project Report 2015-05. https://perma.cc/3GLE -B4Q9 [Last accessed I May 202I].

Spinney, Laura. (2020). 'It takes a whole world to create a new virus, not just China'. The Guardian, 25 March. https://perma.cc/5XLL-8G7X [Last accessed 9 July 2020].

Stein, Samuel. (2019). Capital City: Gentrification and the Real Estate State. UK: Verso. 
Serikat Tani Kota Semarang. (2020). Sekolah di lahan. https://perma.cc/Z9E9 -9GBJ [Last accessed 9 July 2020].

Tacoli, Cecilia. (I998). 'Rural-urban interactions: A guide to the literature'. Environment and Urbanization, vol. Io, no. I, pp. I47-I66. https://doi.org /10.II77/095624789801000105

Yeoh, Brenda. (2005). 'The global cultural city? Spatial imagineering and politics in the (multi)cultural marketplaces of South-East Asia'. Urban Studies, vol.42,no. 5-6,pp.945-958.https://doi.org/Io.1080/00420980500I0720I 